Article

\title{
Carbon-Negative Hydrogen Production (HyBECCS) from Organic Waste Materials in Germany: How to Estimate Bioenergy and Greenhouse Gas Mitigation Potential
}

\author{
Johannes Full 1,2,*(D), Mathias Trauner ${ }^{1}(\mathbb{D})$, Robert Miehe ${ }^{1}(\mathbb{D})$ and Alexander Sauer ${ }^{1,2}(\mathbb{D}$ \\ 1 Fraunhofer Institute for Manufacturing Engineering and Automation IPA, 70569 Stuttgart, Germany; \\ mathias.trauner@ipa.fraunhofer.de (M.T.); robert.miehe@ipa.fraunhofer.de (R.M.); \\ alexander.sauer@ipa.fraunhofer.de (A.S.) \\ 2 Institute for Energy Efficiency in Production (EEP), University of Stuttgart, 70569 Stuttgart, Germany \\ * Correspondence: johannes.full@ipa.fraunhofer.de; Tel.: +49-711-9701434
}

Citation: Full, J.; Trauner, M.; Miehe, R.; Sauer, A. Carbon-Negative Hydrogen Production (HyBECCS) from Organic Waste Materials in Germany: How to Estimate Bioenergy and Greenhouse Gas Mitigation Potential. Energies 2021, 14, 7741. https://doi.org/10.3390/en14227741

Academic Editor: Viviana Cigolott

Received: 7 October 2021

Accepted: 10 November 2021

Published: 18 November 2021

Publisher's Note: MDPI stays neutral with regard to jurisdictional claims in published maps and institutional affiliations.

Copyright: (c) 2021 by the authors. Licensee MDPI, Basel, Switzerland. This article is an open access article distributed under the terms and conditions of the Creative Commons Attribution (CC BY) license (https:// creativecommons.org/licenses/by/ $4.0 /)$.

\begin{abstract}
Hydrogen derived from biomass feedstock (biohydrogen) can play a significant role in Germany's hydrogen economy. However, the bioenergy potential and environmental benefits of biohydrogen production are still largely unknown. Additionally, there are no uniform evaluation methods present for these emerging technologies. Therefore, this paper presents a methodological approach for the evaluation of bioenergy potentials and the attainable environmental impacts of these processes in terms of their carbon footprints. A procedure for determining bioenergy potentials is presented, which provides information on the amount of usable energy after conversion when applied. Therefore, it elaborates a four-step methodical conduct, dealing with available waste materials, uncertainties of early-stage processes, and calculation aspects. The bioenergy to be generated can result in carbon emission savings by substituting fossil energy carriers as well as in negative emissions by applying biohydrogen production with carbon capture and storage (HyBECCS). Hence, a procedure for determining the negative emissions potential is also presented. Moreover, the developed approach can also serve as a guideline for decision makers in research, industry, and politics and might also serve as a basis for further investigations such as implementation strategies or quantification of the benefits of biohydrogen production from organic waste material in Germany.
\end{abstract}

Keywords: HyBECCS; biohydrogen; bioenergy potential; hydrogen; waste-to-hydrogen

\section{Introduction}

The findings in the Sixth Assessment Report of the Intergovernmental Panel on Climate Change (IPCC) show that the $1.5^{\circ} \mathrm{C}$ target is likely already being reached in the timeframe from 2021-2040, with each $1000 \mathrm{GtCO}_{2}$ estimated to increase the global surface temperature from $0.27{ }^{\circ} \mathrm{C}$ to $0.63{ }^{\circ} \mathrm{C}$ and approximately 900 to $2300 \mathrm{GtCO}_{2}$ remaining of the carbon budget to limit warming by $2{ }^{\circ} \mathrm{C}$. A rapid and profound reduction in anthropogenic greenhouse gas emissions from fossil fuel combustion and, in addition, active removal of carbon dioxide from the atmosphere through negative emission technologies (NETs) are inevitably required in the immediate future [1].

In this regard, hydrogen is globally considered to be a key energy carrier of the future to be used as a substitute for fossil energy sources. Germany and many other countries have adopted a hydrogen strategy to bring it into widespread application. Hydrogen can not only be used for fuel or energy storage but is also a key substance of ammonia production or for refineries. In the future, it will be capable of decarbonizing decisive industries, such as steel or cement [2] (p. 2). What distinguishes hydrogen from conventional fuels is that the only combustion product-besides energy-is water. Further, hydrogen gas releases an astonishing amount of $142.35 \mathrm{~kJ}$ per $\mathrm{g}$ when reacting with oxygen. Natural gas, in comparison, releases energy of between 35 and $45 \mathrm{~kJ}$ per $\mathrm{g}$ during combustion [3] 
(p. 42). Hydrogen can be produced sustainably using renewable electrical energy for water electrolysis or from biomass through several processes, with the product being called biohydrogen. Utilizing waste materials for biohydrogen production offers several benefits, as it increases the economic and ecological potential, avoids competitive land use, and represents another step towards a circular economy. According to Full et al. the ecological benefits for climate change mitigation can be further increased by capturing the produced biogenic $\mathrm{CO}_{2}$ during the process and thereby achieving biohydrogen production as a carbon-negative process [4]. This means a net effect of $\mathrm{CO}_{2}$ being removed from-rather than emitted to- the atmosphere during energy generation. This NET approach of carbonnegative hydrogen production by capturing biogenic $\mathrm{CO}_{2}$ during biohydrogen processes is referred to as hydrogen bioenergy with carbon capture and storage (HyBECCS) [4].

There are many different ways to produce renewable energy. Bioenergy is one option that is of great importance, as biomass accounted for about $54 \%$ of the total share of renewable energy in Germany's primary energy consumption in 2017 [5]. A common way of producing bioenergy is the production of biomethane [6]. Biohydrogen production with additional carbon capture and storage or long-term use (HyBECCS) presents an alternative to biogas and -methane production and allows the generation of a carbonnegative product with growing demand $[4,7]$. The development of HyBECCS processes can additionally contribute to the global climate goals by creating negative emissions. Such methods of carbon dioxide removal (CDR) are key measures in the pathways to achieve climate targets [1]. Moreover, in order to decarbonize the energy sector more quickly and sustainably, non-utilized resources such as residual and waste materials should also be harnessed. These resources should be used primarily for NETs, such as the HyBECCS technology, as they are scarce. However, in order to accelerate the development and rollout of such promising technologies, it must be made clear to potential investors that they are economically viable [8]. An analysis of how much bioenergy from waste materials is available and suitable for biohydrogen production provides a basis for making such a statement. Research dealing with the estimation of bioenergy potential already exists [9-16]. However, none of the work deals with bioenergy potentials for biohydrogen production. Hence, there are no uniform evaluation methods for biohydrogen production. Therefore, the overall objective of this paper is summarized by the central question:

'How can the feasible bioenergy potential of several biohydrogen production processes from organic residuals and waste materials in Germany be evaluated and how much reduction in greenhouse gas emissions can be attained as a result?'

Initially, the classification and legal framework of biomass and organic waste materials are analyzed in general. The suggested methodical conduct is presented by the means of an exemplary biotechnological biohydrogen process. These specifications lay the foundation for identifying available material flows suitable to be converted into biohydrogen. After ascertaining and quantifying the amount of utilizable substances, the bioenergy potential can be estimated. Subsequently, this potential can be adopted into a possible amount of non-emitted and captured GHGs using HyBECCS approaches.

In this paper, for the first time, a recommendation for estimating bioenergy potentials specifically tailored for biohydrogen production in the German energy and waste system is developed. Furthermore, it should help to establish a generally accepted method to determine bioenergy potentials in order to make their quantification more accessible and uniform, which will additionally contribute to the development of new emerging technologies and their market rollout.

\section{Basics}

This section lays the foundation for this work by providing essential information regarding the different topics touched upon in this work. 


\subsection{Organic Waste Classification in Germany}

This section outlines the legal framework for renewable energy as well as biomass utilization and disposal in Germany. Moreover, common treatment processes for biomass are presented, briefly touching upon their (dis)advantages and products. Lastly, two significant challenges concerning biomass are outlined, which are also highly relevant to this work.

The general regulation concerning renewable energies is the Renewable Energy Act (orig. Erneuerbare-Energien-Gesetz, EEG), which serves the purpose of enabling sustainable development of energy supply, reducing the economic costs by including long-term external effects, saving fossil resources, and supporting the development of technologies which generate electricity from renewable sources [\$1, EEG]. A key development in the 2021 amendment of the law is that carbon neutrality of German electricity by 2050 and a $65 \%$ share of renewable energy by 2030 are made statutory [17]. The application of the EEG regarding the biomass definition, utilization technologies, and environmental requirements is established in the Biomass Ordinance (orig. Biomasseverordnung, BiomasseV). At the same time, the Circular Economy Act (orig. Kreislaufwirtschaftsgesetz, KrWG) aims to support a circular economy in order to save natural resources and to protect people and the environment during waste generation and management [\$1, KrWG]. More specifically, the treatment, utilization, and disposal of organic waste material are widely regulated in the Organic Waste Ordinance (orig. Bioabfallverordnung, BioAbfV). Material of animal origin falls within the scope of the Animal By-Products Disposal Ordinance (orig. Tierische Nebenprodukte-Beseitigungsverordnung, TierNebV), which sets additional requirements on how such material is handled and disposed of, due to its potential hazard for the health of humans and animals. Data collection, processing, and publication are regulated by the Environmental Statistics Act (orig. Umweltstatistikgesetz, UStatG), which delivers a foundation for (environmental) policy decision making and fulfills the reporting obligation to European and other institutions [18]. German waste statistics are published annually by the German Federal Statistical Office (orig. Statistisches Bundesamt) on its GENESIS-online database, which is open access and provides a list of all waste types and their respective annual amounts. The different types of waste and their respective hazardousness are defined in the German Waste Classification Ordinance (orig. Abfallverzeichnisverordnung, AVV), which transposed the European Waste List into German national law. This work draws upon the definition of biomass from the BiomasseV. It defines biomass as energy sources consisting of phytomass and zoomass, including secondary products, by-products, residues, and wastes of which the energy content originates from phytomass and zoomass $[(1), \S 2$, BiomasseV]. In accordance with the KrWG, waste means any substance or object which the holder discards or intends or is required to discard [(1),\$3, KrWG]. By-products are a substance or object resulting from a production process, the primary aim of which is not the production of that substance or object. They are different from waste if they meet the following criteria:

1. Further use of the substance or object is certain;

2. The substance or object can be used directly without any further processing other than normal industrial practice;

3. The substance or object is produced as an integral part of a production process;

4. Further use is lawful, i.e., the substance or object fulfills all relevant product, environmental, and health protection requirements for the specific use and will not lead to overall adverse environmental or human health impacts [(1),\$4, KrWG].

The term residue is not defined specifically but used in various works and legal documents. As a consequence, the term cannot be clearly distinguished from waste or by-products. In this work, all biomass material, which is not produced as a primary product, falls within the definition of residues. That includes by-products and waste [19] (p. 21). In general, the sectors of agriculture, forestry, fisheries, food production, animal feed production, and municipalities are mainly accountable for organic residues and wastes in Germany [20] (p. 39). All varieties of material such as wastes from livestock farming, 
fish and animal processing, crop harvesting, fruit and vegetable agriculture and processing to organic household waste, green waste, sewage sludge, and secondary wastes need to be evaluated regarding their potential usability for biohydrogen production. Therefore, this work classifies the present biomass flows as listed in Annex 6 of Brosowski et al. [21], as their work provides estimations of potential material flows from the German Biomass Research Centre, DBFZ.

Organic wastes can be used via several pathways, depending on the origin and composition of the material. First, organic material can be used directly, such as animal excrements as fertilizer, bark as mulch, or food industry residues as animal feed. Harvest residues are often left on the field as well [22] (p. 81). Second, various composting processes are established, which treat the material in order to be consecutively applied to (agricultural) land. Advantages are that the stabilized organic substances in compost contribute to the formation of humus, which sustains the productivity of land and increases the water storing capacity of the surface soil [23] (pp. 11,12). Third, energetic use can be realized by fermenting organic material under anaerobic conditions, incinerating material of suitable composition, or using gasification as a means of treatment. Anaerobic fermentation is mainly used for animal excrements, but also for household biowaste or industry residues to a certain extent [24] (p. 38). Sewage sludge is also treated anaerobically on the site of large water treatment plants, whereas the majority of smaller ones have no such treatment option [25] (p. 18). The desired product of anaerobic digestion is biogas, which can be used directly in a combined heat and power plant or treated further to obtain biomethane, which can be fed into the gas grid, for instance. Biohydrogen production from biomass is also a promising utilization pathway in the future. Incineration or gasification is possible for material with low water content that is not usable for fermentation. As a consequence, mainly wood, wood-like residues, or straw are used as input material for those processes [25] (pp. 10-13). Lastly, biodiesel production is a widely applied technology to utilize oils and fats via transesterification [25] (p. 17).

At present, a lot of organic waste material is not used efficiently. It should be noted that material use of biomass, which also includes use as animal feed, is generally seen as higher value than energetic use [22] (p. 20), cf. Figure 1. What is considered inefficient is material use of substrates, which could be used energetically prior to material use. Examples are biowaste or animal excrements, which could be utilized energetically first and subsequently be composted and/or applied to land. This multiple-use principle is suggested to be a more efficient way to utilize organic wastes $[22,26]$ and is also part of the Circular Economy Act [§8, KrWG]. Currently, just $40 \%$ of organic household waste, $12 \%$ of manure, and $2 \%$ of dung are utilized energetically [24,27], even though it would not impede the subsequent material use. In the following, only material flows which do not compete with established, high-value utilization routes such as animal feed, for instance, will be considered. In addition, the material is only analyzed for biohydrogen production, if it is not directly competing with food production or other human use. Overall, this work is based on the principles that food production is prioritized over energy crop cultivation in all cases and focuses on the utilization of true waste products, avoiding material which can be treated through a utilization path of higher value, cf. Figure 1. In consequence, certain biomass flows, theoretically utilizable for biohydrogen production, will be discarded, as higher-value utilization is assumed. However, biomass flows with an established material utilization pathway in which their potential is not harnessed will also be considered available for this process. Animal excrements are an example of that. Further, usable municipal wastes and certain industrial residues can be considered available for biohydrogen production. 


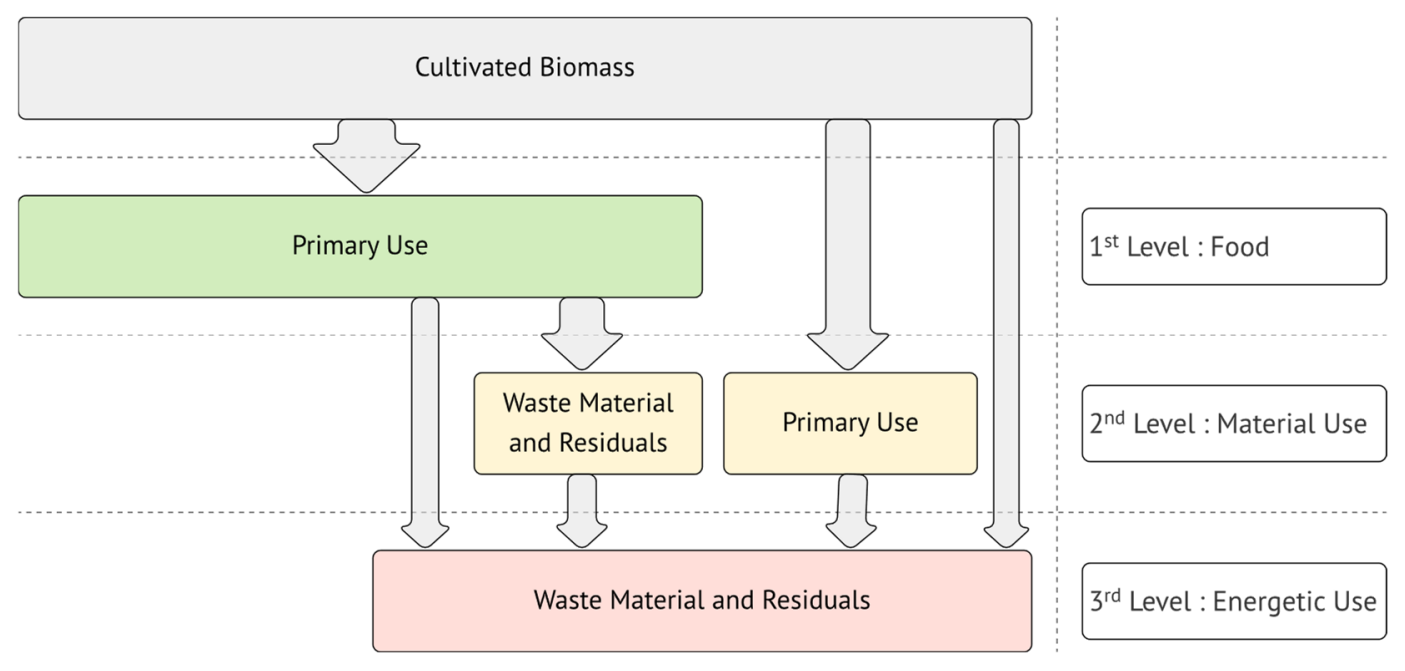

Figure 1. Hierarchy of use for biomass [22].

Another challenge is that, as of 2020,39\% of mixed municipal solid waste (MMSW) is still of native organic origin [28]. This fact is problematic for several reasons. First, the EU set the goal to recycle $60 \%$ of municipal wastes by 2030, which urges Germany to act [28] (p. 26). Redirecting organic material from mixed fractions to biowaste could be a crucial opportunity to do so, as $97 \%$ of separately collected material from the organic waste bin is already being recycled [29] (p. 30). Secondly, organic waste, with its relatively high water content and hence lower caloric value, is not a desired input material for thermal treatment, which is the major route of disposal for mixed municipal waste [29] (p. 30). Even though organic waste is not causing problems in incineration, the desired high-quality utilization of biomass for biogas or, in this case, biohydrogen with multiple uses, is again preferred and demanded by the Circular Economy Act [24] (p. 92).The separate collection of recyclables and organic waste is already mandatory, but the necessary collection systems are not yet implemented consistently [28] (p. 27).

\subsection{Biohydrogen Production and the HyBECCS Approach}

Hydrogen produced from renewable energy or biomass is called green hydrogen as it is $\mathrm{CO}_{2}$ neutral [30]. Furthermore, hydrogen derived from biomass feedstock is called biohydrogen. Processes for producing such green biohydrogen comprise electrochemical, thermochemical, and biotechnological production routes. Microbial electrolysis represents the electrochemical pathway. Thermochemical biohydrogen production processes comprise pyrolysis and gasification, whereas biotechnological process options are biophotolysis, photo-fermentation, dark fermentation, and dark photosynthesis. The following summary is limited to a number of relevant technologies according to the material source. Each technology is briefly described in 2.2.1. Further, in 2.2.2., the HyBECCS approach is presented, which is, at present, the only known way to produce hydrogen with a negative carbon footprint [4].

\subsubsection{Biohydrogen Technologies}

Thermochemical biohydrogen production processes include, for example, pyrolysis and gasification. Pyrolysis is gasification under the absence of oxygen at temperatures between 500 and $900{ }^{\circ} \mathrm{C}$ and pressures between 0.1 and $0.5 \mathrm{MPa}$. As a result, no dioxins or carbon oxides are formed, given that the input material is dry and no air or oxygen is present. The products are synthesis gas and carbon residues, such as liquid oils and solid charcoal [31] (p. 14), see reaction (1.1) in Table 1. Advantages of the process are the wide variety of possible input materials, a simple underlying process, compact plants, a clean carbon by-product (fuel oil or char), and reduced $\mathrm{CO}$ or $\mathrm{CO}_{2}$ emissions compared to gasification [32] (p. 5). That is, the hydrogen produced from biomass conversion can 
be classified as green, due to the carbon-neutral nature of all biomass. In other words, the resulting GHGs during the processes were already removed from the atmosphere in the first place. Biomass is seen as the most feasible candidate to substitute fossil fuels in the near future [32] (p. 5) and thermochemical processes, especially gasification, are already mature. However, biomass conversion faces logistics issues since it requires enormous amounts of input material in large-scale plants. Another problem is tar fouling the plant and the produced gas, which impedes wider market implementation. Possible solutions for the logistics issue are efficient plant downscaling and the smart distribution of conversion plants [32] (p. 5), paving the way for thermochemical processes as the only non-biological means of hydrogen production from biomass [31] (p. 13).

Table 1. Overview of chemical reactions for $\mathrm{H}_{2}$ production from biomass [32-34].

\begin{tabular}{ccc}
\hline Number & Process & Reaction \\
\hline$(1.1)$ & Biomass pyrolysis & $\mathrm{C}_{n} \mathrm{H}_{m} \rightarrow n \mathrm{C}+0.5 m \mathrm{H}_{2}$ \\
$(1.2)$ & Glucose formation & $6 \mathrm{H}_{2} \mathrm{O}+6 \mathrm{CO}_{2} \rightarrow \mathrm{C}_{6} \mathrm{H}_{12} \mathrm{O}_{6}+6 \mathrm{O}_{2}$ \\
$(1.3)$ & Enzymatic hydrogen generation & $\mathrm{C}_{6} \mathrm{H}_{12} \mathrm{O}_{6}+6 \mathrm{H}_{2} \mathrm{O} \rightarrow 6 \mathrm{CO}_{2}+12 \mathrm{H}_{2}$ \\
$(1.4)$ & Microbial electrolysis (acetate) & $\mathrm{CH}_{3} \mathrm{COO}^{-}+4 \mathrm{H}_{2} \mathrm{O} \rightarrow 2 \mathrm{HCO}_{3}^{-}+\mathrm{H}^{+}+4 \mathrm{H}_{2}$ \\
$(1.5)$ & Photo-fermentation (acetic acid) & $\mathrm{CH}_{3} \mathrm{COOH}_{2} \mathrm{H}_{2} \mathrm{O} \rightarrow 4 \mathrm{H}_{2}+2 \mathrm{CO}_{2}$ \\
$(1.6)$ & Acidogenesis (butyric acid) & $\mathrm{C}_{6} \mathrm{H}_{12} \mathrm{O}_{6} \rightarrow \mathrm{CH}_{3} \mathrm{CH}_{2} \mathrm{CH}_{2} \mathrm{COOH}+2 \mathrm{CO}_{2}+2 \mathrm{H}_{2}$ \\
\hline
\end{tabular}

One of the biotechnological process options is biophotolysis. In this process, lightsensitive microorganisms in illuminated reactors perform photosynthesis first to convert water and $\mathrm{CO}_{2}$ to glucose and oxygen (1.2) before photo-activated enzymes split the sugar and release hydrogen gas (1.3). Microalgae are promising organisms for this process, as they can be cultured and allow better hydrogen capture. In general, the process happens under standard conditions in a water environment and does not require cost-intensive input material, although the sufficient illumination of the substrate is an arising upscaling issue [34] (p. 11101). Moreover, the hydrogenase is inhibited by $\mathrm{O}_{2}$, which presents an additional obstacle in the process [33] (p. 8).

Another process, microbial electrolysis, is based on the ability of certain microorganisms, called exoelectrogenic microbes, to produce electric current by oxidizing organic matters. To generate hydrogen, a small external power supply drives electrons-produced from organic matter in the anode chamber-through a wire to the cathode. The applied current is typically $0.2 \mathrm{~V}$, which is very low compared to $1.6-1.8 \mathrm{~V}$ for water electrolysis [33] (p. 11). Together with protons, which permeate through the proton exchange membrane, the electrons form hydrogen gas in the cathode chamber. An exemplary reaction for acetate as an organic compound (1.4) is shown in Table 1. This system is called a microbial electrolysis cell, which presents high hydrogen yields and efficiencies. However, the performance depends on the microbes used and the exchange efficiency of the membrane, as well as on the electrical conductivity and chemical stability of anode and cathode. Additional tasks are the reduction in internal resistance and material cost, as well as the increase in biomass concentration in the anode chamber [33] (p. 11, 12).

Photo-fermentative purple and green bacteria are able to preferably convert organic acids, but also carbohydrates or industrial effluents, to $\mathrm{H}_{2}$ and $\mathrm{CO}_{2}$, utilizing energy from light in anaerobic environments $[33,35]$. An exemplary reaction of this photo-fermentation process is executed by purple non-sulfur bacteria, as shown for acetic acid (1.5) in Table 1. The process is highly sensitive to the presence of oxygen or ammonia and depends on light intensity, carbon source, and type of microorganism [35] (p. 575). The utilization of solar energy and organic wastes promises cheap operation. However, as hydrogen production rates and efficiencies for light conversion are low, while reactor costs are high and illumination problems immense, the process is rather impractical [33] (p. 9).

Compared to photo-fermentation and bio-photolysis, the so-called dark fermentation provides the huge advantage of not being dependent on light as well as featuring simple reactor design and operation [33] (p. 10). The main idea in dark fermentation is to inhibit the hydrogen-consuming methanogenesis, which is the last step of an anaerobic biogas 
process, and harvest the hydrogen. The environment can be mesophilic, thermophilic, or hyperthermophilic, depending on the microbial strain to be used for production [36] (pp. 24, 25). The acidogenic phase particularly degrades carbohydrates, fats, and proteins to volatile fatty acids (VFAs), alcohols, amino acids, $\mathrm{H}_{2}$, and $\mathrm{CO}_{2}$. For example, pyruvatean intermediate in the metabolization of glucose-is converted to volatile fatty acids, e.g., acetic, butyric, propionic, and malic acid, and hydrogen [31] (p. 9). As an example, the reaction of glucose to butyric acid (1.6) is shown in Table 1. Due to the similarity to the classical biogas process, dark fermentation is seen as a feasible way to produce hydrogen from organic wastes. However, low hydrogen yields and substrate degradation need to be optimized. To achieve that, process operation is still a matter of development, with the suppression of methanogens being crucial to the final hydrogen yield [32] (p. 11).

The so-called dark photosynthesis process is defined by the possibility of accomplishing photosynthetic growth patterns for Rhodospirillum rubrum, a Gram-negative, nonsulfur purple bacterium and a facultative anaerobe, with a special culture medium under dark conditions. This growth medium, called M2SF, is capable of enabling mass cultivation under semi-aerobic dark conditions. Such behavior is usually limited to anaerobic, photoheterotrophic growth $[37,38]$. The result of this new means of growth-mimicking light signals to the photosynthetic genes in a dark environment-is that the versatile metabolism of R. rubrum can be utilized in the absence of light, which makes it perfectly scalable.

\subsubsection{The HyBECCS Approach}

According to the sixth assessment report of the IPCC, emissions pathways that limit global average warming to $1.5^{\circ} \mathrm{C}$ or $2{ }^{\circ} \mathrm{C}$ by 2100 require the use of carbon dioxide removal (CDR) approaches in combination with emissions reductions to pursue a pathway with net negative $\mathrm{CO}_{2}$ emissions from 2050 on. Hence, affordable as well as environmentally and socially responsible CDR options on a large scale well before 2050 are an important element for climate mitigation and play a central role in limiting global warming to $1.5^{\circ} \mathrm{C}$ or $2{ }^{\circ} \mathrm{C}$ [1]. Negative emission technologies (NETs), of which bioenergy carbon capture and storage (BECCS) as well as ocean fertilization, mineral carbonation, afforestation, and direct air capture (DAC) are part, are important by means of reducing anthropogenic net emissions in the near future [39] (pp. 1124, 1125). An emerging subclass of BECCS technologies is the concept of hydrogen bioenergy coupled with carbon capture and storage (CCS) technology [4]. These process combinations, referred to as HyBECCS, are described briefly below.

Most of the biohydrogen technologies are able to split biomass substrates into $\mathrm{H}_{2}$ and $\mathrm{CO}_{2}$, which is beneficial for an effective carbon capturing process, as this mixture can be separated. The hydrogen fraction can be used to substitute fossil energy carriers in industry or transport in order to decarbonize these sectors. The carbon dioxide can be put to long-term use or in storage, leading to a carbon sink since it was previously removed from the atmosphere through plant biomass growth in relatively short periods of time. Carbon dioxide storage possibilities include enhanced oil or gas recovery, storage in saline formations, depleted oil and gas fields, and others [39] (Figure 1). An alternative to storage is usage, where $\mathrm{CO}_{2}$ is stored for a certain period of time in applications such as fuels, construction materials, chemicals, and plastics [39]. All process combinations referred to as HyBECCS can be split into four basic process steps: biomass pretreatment, biohydrogen production, product gas separation, and its processing. For each of the four steps, there are variable options to be selected and combined into an overall process.

The main technological advantages of HyBECCS over competing NETs are, on the one hand, the energy-efficient capture of $\mathrm{CO}_{2}$ with high purity and concentration compared to DAC approaches. On the other hand, it offers high carbon dioxide removal potential compared to BECCS technologies based on hydrocarbon energy carriers, which emit $\mathrm{CO}_{2}$ during their decentralized use. Based on these advantages, HyBECCS is considered to be a promising and highly effective BECCS approach that is expected to play a major role in future energy systems by making a significant contribution to meeting the world's 
rapidly growing demand for green hydrogen and negative emissions [4]. The HyBECCS approach can also be seen as part of the biological transformation process, which aims to achieve a sustainable economy that is no longer dependent on the depletion of fossil fuels by linking classical production with bio- and information technologies, leading to a new and disruptive innovation space $[40,41]$.

\subsection{Terminology and System Boundaries}

In the past, the term 'potential' was not clearly defined in various studies, decreasing comparability and complicating interpretation. System boundaries define the resulting potentials and need to be chosen to reduce the effort of elaboration, but they still have to support the purpose of a piece of work, so it is strictly necessary to define them precisely. As a result, the terminology and systematic approach for this sort of estimation of potential have been standardized to some extent. In this work, the definitions according to Thrän et al. are used and summarized in the following [19]. The different types of potentials are outlined and their differences, e.g., level of observation and system boundaries, are highlighted and placed in the present context.

Biomass potentials can be differentiated according to the level of consideration [19]. Land potential, feedstock potential, fuel potential, and bioenergy potential can be distinguished. An overview of these levels and the resulting potential terms can be seen in Figure 2. The land potential describes the area available for energy crop cultivation, which is not relevant to this work, as it deals with organic waste material, and the feedstock potential is not calculated from the underlying land potential but represents the amount of applicable material for biohydrogen production. From that point, the fuel potential can be obtained from the hydrogen yield per unit of substrate and the respective lower heating value of $\mathrm{H}_{2}$. Lastly, the bioenergy potential can be derived by considering the relevant conversion efficiency of hydrogen to heat and/or electric energy and the energy input for pretreatment and process operation.

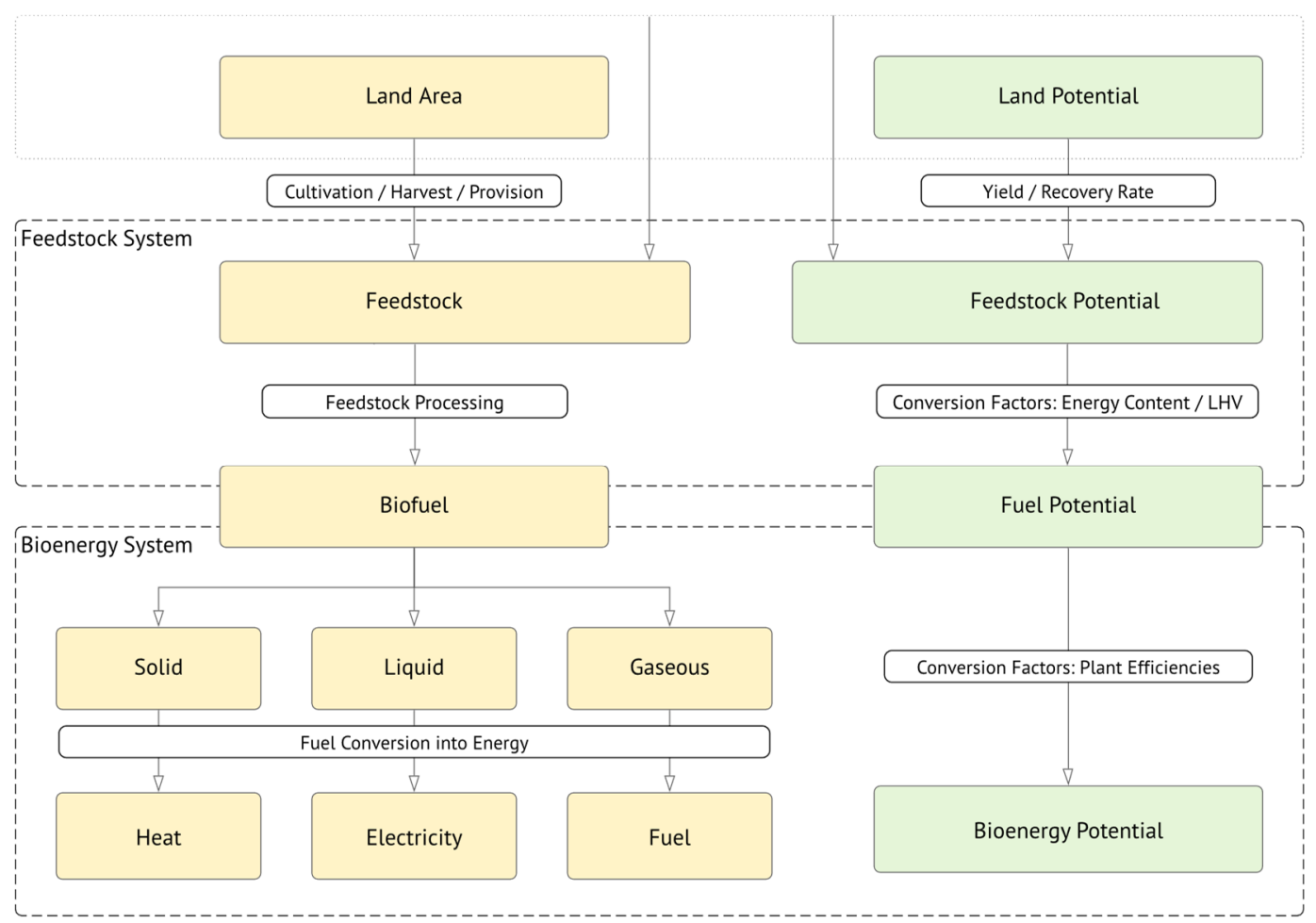

Figure 2. Levels of utilization pathway and corresponding potential terms [19]. 
Each potential requires specific system boundaries and framework conditions, necessitating further explanations. The biomass potentials obtained in a piece of work depend on a variety of different factors, such as the biomass material considered, the geographic level, the temporal reference, the type of data collection, and the methodology of conduction. In addition, different perceptions of competitive usage, sustainability aspects, or nature conservation issues often cause confusion [19] (p. 40).

These aforementioned potentials need to be defined more precisely, as to whether they reflect a theoretical, technical, or other potential. First, a theoretical potential describes the overall energy amount for a specific region in a specified period of time. It resembles the maximum amount of energy supply contained in the considered biomass, as it is based on the physical utilization boundaries alone. The practical relevance is minor, because the theoretical potential provides no statement of the actually usable amount of energy [19] (p. 42).

Second, the technical potential considers certain restrictions, and hence gives a more realistic result of utilizable biomass in a specific region and time. Considered restrictions are of technical (e.g., recovery rates and conversion losses), legal, environmental (e.g., environmental protection regulations, cross-compliance regulation), and social (e.g., food production, material utilization) concern. The technical potential is widely used in studies, as it is less affected by temporal fluctuations than the economic potential, for instance [19] (p. 42).

The economic potential reflects a part of the technical potential, which can be utilized considering further restrictions related to the economic framework. Adding even more restrictions allows for distinguishing additional potential terms. If increased importance is laid on ecological and environmental factors, one is speaking of sustainable biomass potential. Going one step further in the implementation direction, realizable potential can be obtained by further considering sociopolitical and practical restrictions [19] (p. 43).

That is, a scientific piece of work needs to explicitly lay out its use and interpretation of the mentioned terms. Moreover, the boundary conditions such as region, timescale, considered biomass, process operation, material handling, output, and methodical conduct need to be mentioned. An overview of the relevant potential terms is given in Figure 3. The following restrictions are suggested to be included when deriving a technical potential by Thrän et al. [19] (p. 44):

- Societal variables (as general agreement whether certain feedstock should receive a generally preferred form of utilization).

- Technical variables (cultivation, harvest, recovery, and conversion technology).

- Demand for food and material utilization.

- Ecological/environmental variables (legal requirements to ensure a sustainable resource base).

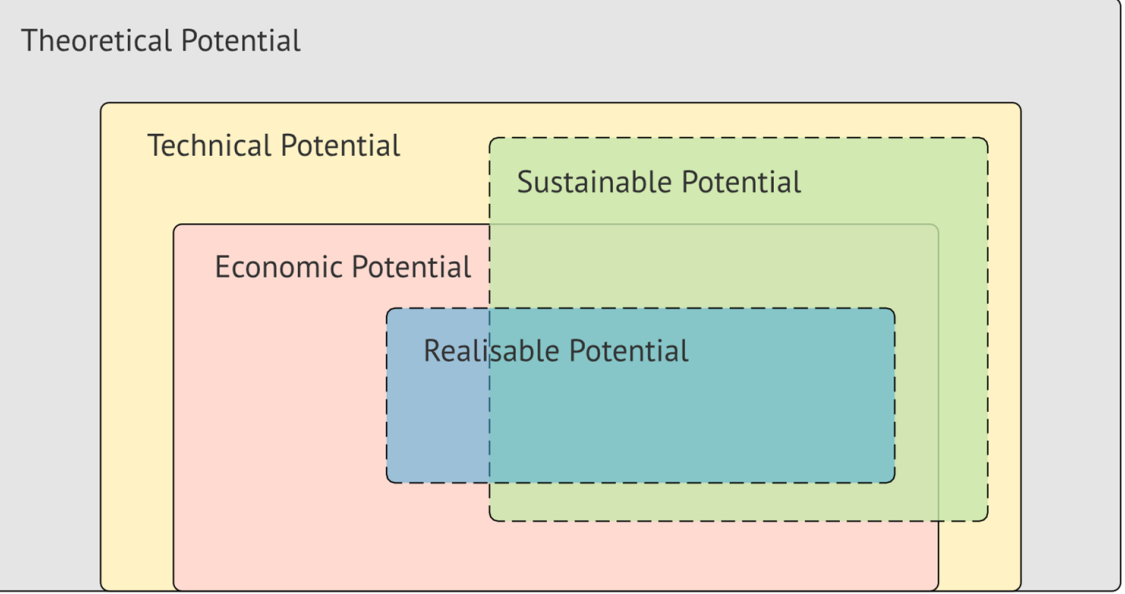

Figure 3. Types of potential according to system boundaries [19]. 
As this work aims to present a methodological approach to derive technical potential for biohydrogen production, these factors are included as far as possible. Some aspects, however, have to be simplified or neglected. Relevant factors, which exceed the scope of this work, are of demographic background, such as population trend, of socio-economic background, such as consumption habits and environmental consciousness, or of policymaking, regulatory, or organizational background, such as improved circular economy, reduced food waste, or stricter EHS standards [22] (p. 84). Other specific topics relevant to this process have not been included, such as substrate logistics, and storage or process residue handling. The restrictions applied to theoretical amounts of waste materials are, together with chosen simplifications and unincluded aspects, laid out in Section 3.

\section{Methodological Approach}

The following presents a systematic four-step methodological approach to obtain bioenergy potential and negative emission potential of biohydrogen production. Each step is elaborated in the following subsections, as shown in Figure 4. In the first step, a procedure to select relevant biomass categories for hydrogen production is elaborated, which is divided into six sub-steps. Second, suggestions are made for assumptions and framework conditions regarding biomass pretreatment, process energy demand, and logistical specifics. In the third step, in order to derive a calculation equation for the determination of the bioenergy potential for biohydrogen production, relevant indicators such as the lower heating value (LHV) or the fuel potential (FP) are introduced. This was done in accordance with standard practice and in compliance with certain criteria intended to ensure comparability and transparency. Finally, the estimation of the negative emission potential of biohydrogen processes is discussed regarding their contributions to climate mitigation. Furthermore, a calculation to estimate the saved amount of $\mathrm{CO}_{2}$ emissions as well as for the substitutable amount of (fossil) energy carriers is presented.

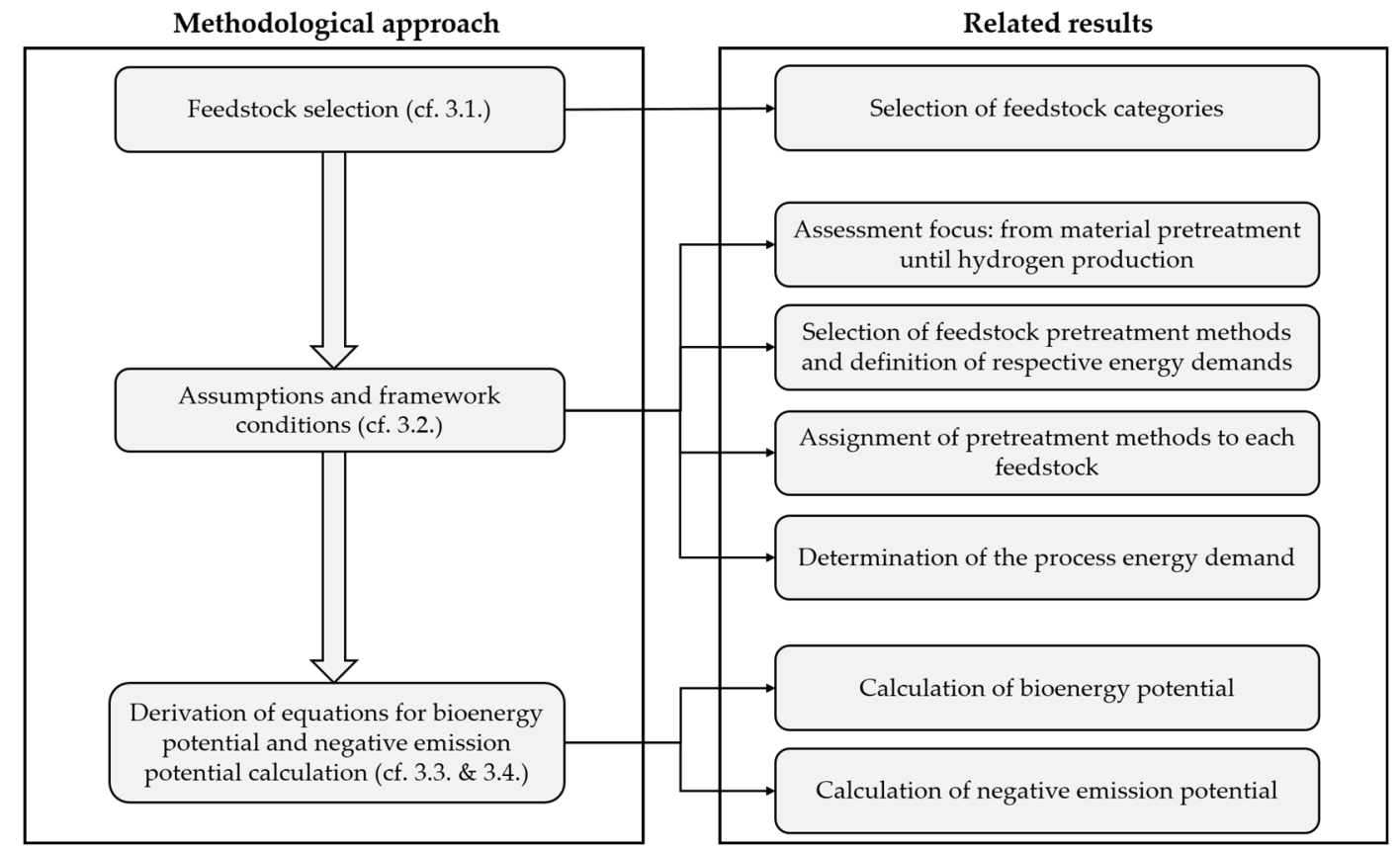

Figure 4. Overview of the presented methodological approach for bioenergy potential estimation and ecological assessment (left) and the respective results (right).

\subsection{Feedstock Selection}

The first and most important step is to identify and quantify biomass flows utilizable for biohydrogen production. These resource streams are the basis, as the hydrogen yield 
and all further results directly depend on the amount of utilizable substrate. Brosowski et al. defined 93 different biomass categories (BCs), which are drawn upon as a foundation for substrate selection in this work. In this section, the different BCs are evaluated regarding their applicability to the considered biohydrogen process, taking into account the prerequisites of the process and the biomass utilization hierarchy. All of the categories can be seen in Annex 6 of Brosowski et al. [21]. The selection process, which is conducted according to the following steps exemplified for biotechnological, fermentative biohydrogen production, can be illustrated in a decision tree as seen in Figure 5:

- Step 1 Data validity, utilization pathways, and classification issues: According to Brosowski et al., data and information are inconsistent for 16 biomass categories (BCs) and no technical potential is presented for eight categories. Those classes are sorted out in this step. Moreover, many food industry wastes, such as coffee or tobacco residues, must be disposed of according to special regulations. Other biomass flows, such as residues from convenience food production, are highly heterogeneous and assumed not to contain large amounts of relevant contents [42] (Chapter 2). Thus, it is not possible to make reasonable assumptions about the composition and such material flows should not be considered for utilization. In this case, 32/93 BCs can be discarded in this step.

- $\quad$ Step 2 Lignocellulosic biomass: Biomass categories containing wood or wood-like waste, straw, stalk, or other green waste are currently not suitable for some biotechnological processes, as they need to be readily biodegradable by microorganisms. Wood essentially consists of cellulose, hemicellulose, and lignin, which are poorly biodegradable without extensive pretreatment. Hence, they are rather unsuitable for fermentative processes [20] (p. 53); 28/93 BCs match this criterion and should be sorted out.

- $\quad$ Step 3 Wastes of animal origin: Such wastes should not be considered for alternative use because of the potentially contagious material and an established industry for efficient utilization of animal origin wastes. Gaida et al. describe the utilization of this biomass as already optimized. For instance, animal skin is processed to leather, and protein-rich residues are processed into tankage or fertilizer. Other potential pathways are biodiesel production and utilization as substances in the oleochemical industry [42] (pp. 22, 24). However, if a special suitability can be derived for specific biohydrogen process options, a comparison with the respective reference processes might be of interest. If not, 2/93 BCs match this criterion and should be sorted out.

- $\quad$ Step 4 Oils and fats: In a comprehensive evaluation of utilization pathways for this category, Fehrenbach et al. found that biodiesel production might be superior to other means of utilization [22] (pp. 112, 179). A comparison of the biohydrogen process under consideration with this form of use is therefore to be initiated. If the comparison is decided in favor of biodiesel production, another 2/93 BCs are sorted out in this step.

- $\quad$ Step 5 Waste material untypical for fermentation: Some waste types can be considered as biomass, but are not readily biodegradable, such as textiles or packaging material. These must also be subjected to a special test to determine their suitability for biohydrogen production. If this test is negative, $2 / 93 \mathrm{BCs}$ match this criterion and have to be sorted out.

- Step 6 Animal feed or low sugar content: According to Section 2.1., material use of biomass should be preferred over energetic use in the case of animal feed, for instance. Hence, plenty of different process residues from the food industry cannot be seen as waste and are consequently not considered in this estimation of potential. Usage competition can arise if such materials are utilized energetically. Residues from the sugar industry would be perfectly suitable for fermentative biohydrogen processes, due to their sugar content. However, this material is widely used as animal feed, in the yeast industry, or in distilleries. The work of Gaida et al. indicates high-value material use for most food industry residues at present [42] (Section 2). However, 
dairy industry residues, which mostly consist of whey [42] (p. 40), are excluded from this step. The amount currently fed to pigs is found to be better used for human consumption, which mainly consists of the contained whey protein [43] (p. 271). The contained lactose, which is a substrate for homolactic fermentation, remains in the permeate after protein extraction, hence it can be considered. Other biomass categories, such as residues from alcohol production, must first be checked as to whether they contain significant amounts of utilizable substances for biohydrogen production. Finally, 17/93 BCs could be excluded in this step.

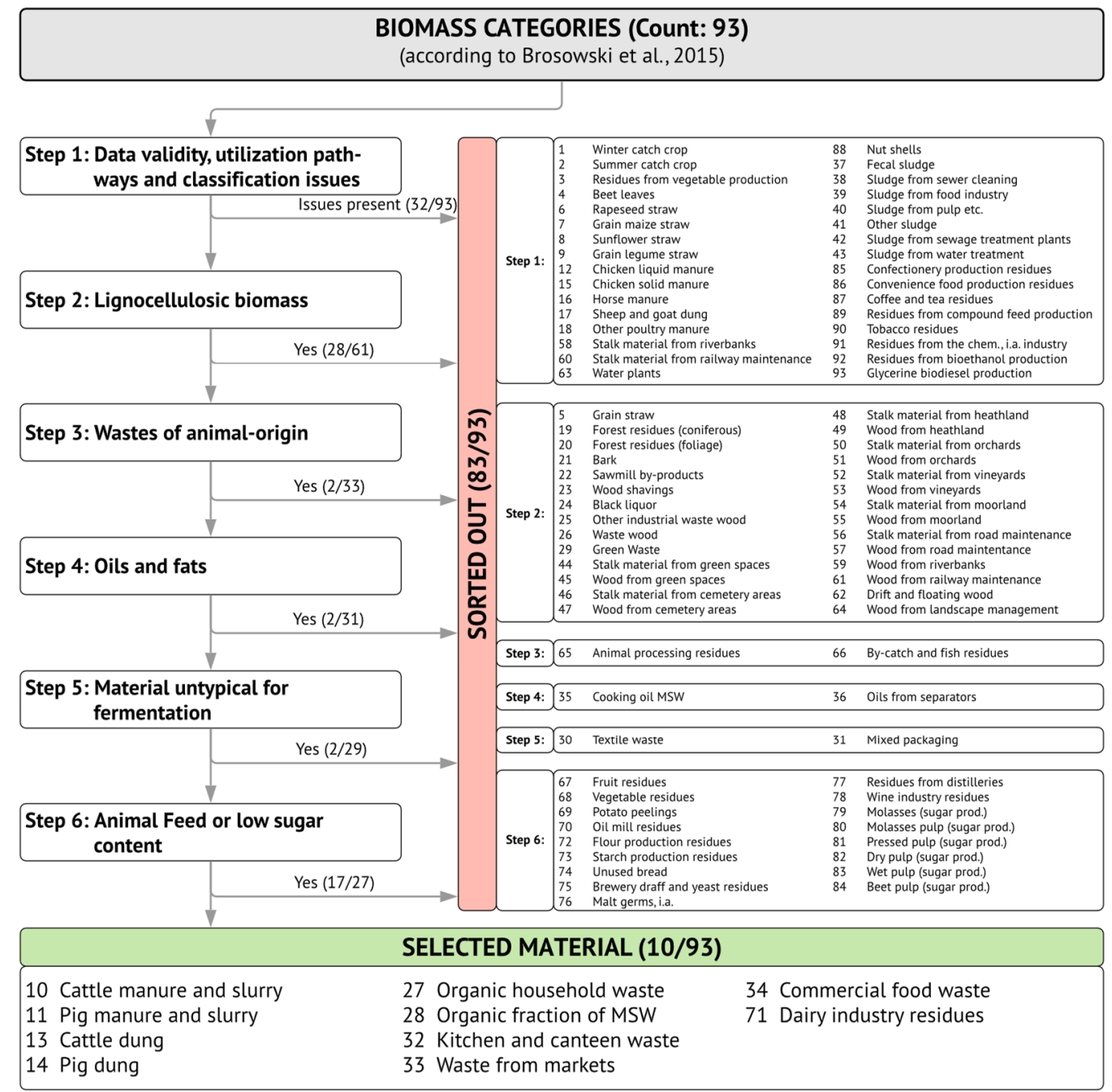

Figure 5. Decision tree to select suitable biomass categories for an exemplary biotechnological biohydrogen process.

In summary, the majority of waste types can be sorted out for this exemplary biotechnological biohydrogen production, as illustrated in Figure 5. Technical feedstock potentials with maximum and minimum values are available in Brosowski et al. [21] for the respective material flows. Since those estimations of potential are of different sources, going as far back as 2000, certain values can be updated where possible. For instance, technical figures of potential are in some cases directly related to official waste statistics, or new values for 2015 can be accessed in the online database of the DBFZ. In the next sections, the waste flows are developed into a technical bioenergy potential by making assumptions according to Sections 3.2 and 3.3. 


\subsection{Definition of Assumptions and Framework Conditions}

This section briefly presents proposed assumptions required by certain steps in the process of developing energy potentials.

\subsubsection{Substrate Pretreatment}

To increase process efficiency and hydrogen output, it is necessary to prevent disruptions and clogging and ensure sufficient homogenization for stable process operation. Additionally, the pretreatment of substrate is essential in biochemical conversion processes [44] (p. 34). The considered pretreatment methods for this exemplary process are grinding, hygienization, and thermochemical hydrolysis. Homolactic fermentation and anaerobic storage are more of a recommended storage option, rather than a pretreatment measure in that sense. Filtration or other more elaborate pretreatments (e.g., fructose extraction) could be required. All of the mentioned processes are shortly described and reasoned in the following. After that, each type of waste is assigned a probably suitable pretreatment method or combination of methods to ensure ideal process operation. This allocation is carried out based on subjective estimations. Certain pretreatments are especially common in biogas processes but are assumed necessary or advantageous for biohydrogen production, especially for biotechnological process routes. The derived energy demands are related to tons of fresh mass (FM).

Grinding $(G)$ : Grinding is a common pretreatment of substrates in biogas processes for several reasons. It increases the surface area, which supports sufficient and fast microbial degradation. In addition, it reduces the risk of issues such as clogging, reduced pumping ability, and agitator stagnation [44] (p. 35). Water or liquids, such as dairy industry residues, can be added during grinding to transform the substrate into the right condition. For the energy demand of grinding, a shredder $(P=37 \mathrm{~kW}$ with a throughput of $15 \mathrm{t} / \mathrm{h})$ was adduced as an example. This results in an electric energy demand of $W_{\mathrm{el}}=2.46 \mathrm{kWh} / \mathrm{t} \hat{=} 8.9 \mathrm{MJ} / \mathrm{t}$.

Hygienization $(\mathrm{H})$ : As the selected material flows can include smaller amounts of material from animal origin, e.g., municipal waste, hygienization could be necessary. If no material from category 1 or 2 (except animal feces, which are subject to exceptions) is assumed to be in the selected material, pasteurization at $70{ }^{\circ} \mathrm{C}$ for $60 \mathrm{~min}$ (Cat. 3: ground to $<12 \mathrm{~mm}$ ) is a sufficient treatment, according to Regulation (EC) No 1774/2002 Annex VI, Chapter II, C. In this work, pasteurization is considered sufficient to ensure hygienic input substrate. Besides that, pasteurization might trigger certain hydrolysis processes in the material and consequently increase process output. An advanced sterilization method would be pressure sterilization $\left(133^{\circ} \mathrm{C}, 3\right.$ bar for at least $20 \mathrm{~min}$ ), which could be used if pasteurization does not achieve satisfactory bacterial reduction. The energy demand for pasteurization can be considered as follows:

- $\quad$ electric: $\mathrm{W}_{\mathrm{el}}=2.5 \mathrm{kWh} / \mathrm{t} \hat{=} 9 \mathrm{MJ} / \mathrm{t}\left(\mathrm{W}_{\mathrm{el}}=2.1-2: 3 \mathrm{kWh} / \mathrm{m}^{3}\right.$ [45] (p. 105); assumed substrate density $1000 \mathrm{~kg} / \mathrm{m}^{3}$ );

- thermal: $\mathrm{W}_{\text {th }}=12 \mathrm{kWh} / \mathrm{t} \hat{=} 43.2 \mathrm{MJ} / \mathrm{t}\left(\mathrm{W}_{\text {th }}=11.6-11.9 \mathrm{kWh} / \mathrm{m}^{3}\right.$ [45] (p. 105).

Thermochemical hydrolysis (TCH): Vavouraki, Angelis, and Kornaros showed that a lot of glucose can be mobilized in kitchen wastes through thermochemical hydrolysis (TCH) by relatively simple hydrochloric acid pretreatment. As all material needs to be hygienized, especially for biotechnological biohydrogen production, this process can be used for additional sugar mobilization. Tests showed that glucose content can be increased by almost $600 \%$ by treating kitchen wastes at $100{ }^{\circ} \mathrm{C}$ with $1.12 \%$ added hydrochloric acid for a period of $108 \mathrm{~min}$ [46] (p. 744). It is assumed that the thermal energy demand is higher by $50 \%$ than for hygienization while the electrical one remains equal. It should be noted that hydrolyzed material requires subsequent neutralization to not harm the culture. The energy demand for TCH can be considered as follows:

- $\quad$ electric: $\mathrm{W}_{\mathrm{el}}=2.5 \mathrm{kWh} / \mathrm{t} \hat{=} 9 \mathrm{MJ} / \mathrm{t}\left(\mathrm{W}_{\mathrm{el}}=2.1-2.3 \mathrm{kWh} / \mathrm{m}^{3}\right.$ [45] (p. 105); assumed substrate density $1000 \mathrm{~kg} / \mathrm{m}^{3}$ );

- thermal: $\mathrm{W}_{\text {th }}=18 \mathrm{kWh} / \mathrm{t} \hat{=} 64.8 \mathrm{MJ} / \mathrm{t}$. 
The controlled anaerobic storage (AS) of animal excrements enables an initial hydrolysis process, in which VFAs are produced [47] (p. 160). In consequence, anaerobically stored slurry and manure present a significantly higher content of VFAs, which are considered utilizable for certain biohydrogen processes. The temperatures observed in [47] ranged between close to 0 and almost $25^{\circ} \mathrm{C}$, therefore no thermal energy input is assumed. The electrical energy input is neglected.

Enhanced homolactic fermentation (HLF) is another suitable pretreatment step for wastes from the dairy industry. In this step, lactic acid is produced, which is utilizable for some biohydrogen processes. Dairy products, especially whey, are suitable raw materials as they already contain lactic acid-producing bacteria and important nutrients such as lactose [48] (p. 2). As the process temperatures range between 5 and $45^{\circ} \mathrm{C}$, no energy input must be considered for this pretreatment. Further details, such as reactor type, retention times, or potential additives, are not further discussed in this work.

All pretreatment methods, including the respective energy demands, are listed in Table 2. In addition, a suitable pretreatment or a combination of pretreatments is assigned to each type of biomass, which can be seen in Table 3 .

Table 2. Overview of energy demands for pretreatment methods.

\begin{tabular}{|c|c|c|c|}
\hline \multicolumn{2}{|c|}{ Method } & \multicolumn{2}{|c|}{ Energy Demand } \\
\hline Symbol & Name & $\mathrm{W}_{\mathrm{el}}$ in $\mathrm{MJ} / \mathrm{t}$ & $\mathrm{W}_{\mathrm{th}}$ in $\mathrm{MJ} / \mathrm{t}$ \\
\hline (G) & Grinding & 8.9 & 0 * \\
\hline (H) & Hygienization & 9 & 43.2 \\
\hline$(\mathrm{TCH})$ & $\begin{array}{c}\text { Thermochemical } \\
\text { hydrolysis }\end{array}$ & 9 & 64.8 \\
\hline (AS) & Anaerobic storage & 0 * & 0 * \\
\hline (HLF) & $\begin{array}{l}\text { Homolactic } \\
\text { fermentation }\end{array}$ & 0 * & 0 * \\
\hline
\end{tabular}

${ }^{*}$ No energy input allocated or negligible as described in Section 3.2.1.

Table 3. Overview of selected pretreatment for each type of waste.

\begin{tabular}{lccccc}
\hline \multicolumn{1}{r}{ Biomass Category } & \multicolumn{5}{c}{ Pretreatment } \\
\cline { 2 - 6 } & (G) & (H) & (TCH) & (AS) & (HLF) \\
\hline Cattle manure and slurry & & $\mathrm{x}$ & & $\mathrm{x}$ & \\
Pig manure and slurry & & $\mathrm{x}$ & & $\mathrm{x}$ & \\
Cattle dung & $\mathrm{x}$ & $\mathrm{x}$ & & $\mathrm{x}$ & \\
Pig dung & $\mathrm{x}$ & $\mathrm{x}$ & & $\mathrm{x}$ & \\
Organic household waste & $\mathrm{x}$ & & $\mathrm{x}$ & & \\
Kitchen and canteen waste & $\mathrm{x}$ & & $\mathrm{x}$ & & \\
Waste from markets & $\mathrm{x}$ & & $\mathrm{x}$ & & $\mathrm{x}$ \\
Dairy industry residues & & $\mathrm{x}$ & & & \\
Organic fraction of MSW & $\mathrm{x}$ & & $\mathrm{x}$ & & \\
Commercial food waste & $\mathrm{x}$ & & $\mathrm{x}$ & & \\
\hline
\end{tabular}

\subsubsection{Process Energy Demand}

As the process requires similar technical equipment and reactor design compared to a biogas process (e.g., agitators, pumps), the overall process energy demand for biotechnological biohydrogen processes can be estimated by average figures for biogas production from the Agency for Renewable Resources (orig. Fachagentur Nachwachsende Rohstoffe e. V., FNR). Energy-demanding features for biohydrogen-specific subprocesses have to be estimated separately or can be neglected in some cases. The FNR publishes key figures from several sources and its own calculations on its webpage, where the estimated figures represent percentages of the plant's total energy output. Pasteurization and thermochemical hydrolysis already preheat the material, therefore the actual thermal energy demand 
(heating) of the bioreactors can be neglected in this case. Preheated substrate from pasteurization is assumed to maintain process temperatures between 25 and $30{ }^{\circ} \mathrm{C}$. The process energy demand is estimated to be $7.6 \%$ electric $\left(f_{e l}\right)[49]$ and, due to the aforementioned reasons, $0 \%$ instead of $28 \%$ thermal $\left(f_{t h}\right)$ of the overall energy generation capacity.

\subsubsection{Logistics, Substrate Storage, and Handling of Residues}

A comprehensive assessment of technical energy potentials is a multi-faceted challenge, which also requires examination of the material throughout its life cycle. For biohydrogen processes, real sustainability also includes avoiding long transport routes, efficient use of existing infrastructure, and material sources, among other aspects. This paper does not cover such aspects, due to their complex nature, regional variation, and the lack of traceability for waste materials on a large-scale basis. Such elaborate factors are found to be difficult to generalize due to the wide variety of possible hydrogen production options, and hence are to be assessed on a case-by-case basis. In the scope of this work, the process impact is evaluated from material pretreatment until hydrogen generation. The residues of the process can contain additional potential, which could further enhance the efficiency of the overall utilization. In any case, the material needs to be disposed of or treated by other means consecutively.

\subsubsection{Produce Gas Separation}

Depending on the biohydrogen production process, the initial produce or synthesis gas may be composed of various compounds. For biotechnological biohydrogen production, occurring produce gas compounds include $\mathrm{CO}_{2}$ and $\mathrm{H}_{2}$ and may contain $\mathrm{N}_{2}$, water vapor, or trace compounds such as $\mathrm{NH}_{3}, \mathrm{CO}$, and $\mathrm{H}_{2} \mathrm{~S}$, for instance [50,51]. As fuel cell technology demands high hydrogen purities (99.99\%), effective separation is a key process in biohydrogen production [51] (p. 1277). Common separation systems include scrubbing, pressure swing adsorption, and cryogenic separation, all of which are energy intensive, and membrane technologies show great potential, but many are still in development [31,51]. Membrane technologies allow for simple separation at lower energy requirements, hence further development of these technologies is essential for biohydrogen production as a whole. The detailed consideration of energy inputs during this part of a production process is not part of this work. Nevertheless, this process step and its related energy inputs demand consideration in bioenergy potential estimations and should be included in future research and case studies.

\subsection{Calculation of Energy Potential}

In this step, the obtained feedstock potential and producible hydrogen can be converted into fuel and bioenergy potentials, respectively. With an established amount of moles $\mathrm{H}_{2}\left(n_{\mathrm{H}_{2}}\right)$, the annual mass of hydrogen gas output $\left(m_{\mathrm{H}_{2}}\right)$ can be calculated. The total energy content of an energy carrier is described either by the higher heating value $(H H V)$ or the lower heating value $(L H V)$, with combustion being the underlying process. The difference between $H H V$ and $L H V$ is that $H H V$ assumes the produced water to be in a liquid state. Combustions usually include fuel of organic origin or, in this case, hydrogen, which reacts with oxygen. The reaction products are $\mathrm{CO}_{2}$ and $\mathrm{H}_{2} \mathrm{O}$ for carbon-containing sources and $\mathrm{H}_{2} \mathrm{O}$ for hydrogen. In practice, the heat generation causes water to evaporate, hence the $H H V$ can only be achieved if the flue gas energy is also fully harnessed, which is not always possible [48] (p. 23). As a result, the $L H V$ is used to determine the utilizable energy content in this work. For hydrogen gas, the $L H V$ is $120 \mathrm{MJ}$ per $\mathrm{kg}$ [36] (p. 239). The resulting fuel potential $(F P)$ can be calculated according to Equation (1).

$$
F P=m_{\mathrm{H}_{2}} \cdot L H V_{\mathrm{H}_{2}}
$$

The overall energy conversion efficiency of modern fuel cells can be as high as $90 \%$, with 45-60\% electrical. Hydrogen-only operation of such cells, which currently mostly use natural gas as fuel, can bring several benefits and even higher efficiencies [52] (pp. 
$374,377)$. This work considers an overall conversion efficiency of $90 \%$ total $\left(\eta_{t o t}\right)$ and $50 \%$ electrical efficiency. In addition, the energy demands for substrate pretreatment $\left(W_{P T}\right)$ and process operation $\left(W_{P O}\right)$, which reduce the overall energy output, are considered in this final step. The respective energy amount of pretreatment is calculated by summing up the electric and thermal energy consumption for each method, see Equation (2). To include the process energy demand, the bioenergy potential can be reduced by the factors of Section 3.2.2 $\left(\mathrm{f}_{\mathrm{el}}\right.$ and $\left.\mathrm{f}_{\mathrm{th}}\right)$. The resulting bioenergy potential $(B E P)$ is the final, utilizable amount of energy after conversion [19] (p. 41), reduced by the amount of energy consumed by pretreatment and process operation, and is calculated according to Equation (3). Additional energy inputs from logistics, storage, residue treatment, or gas separation can be included here for more detailed case studies.

$$
\begin{gathered}
W_{P T}=W_{G}+W_{H}+W_{T C H}+W_{A S}+W_{H L F} \\
B E P=F P \cdot \eta_{t o t} \cdot(1-\mathrm{fel}-\mathrm{fth})-W_{P T}
\end{gathered}
$$

\subsection{Negative Emission Potential Estimation}

In the last step, the environmental impact of the biohydrogen process is estimated. Aspects such as the achievable substitution of other energy carriers and the resulting emission reduction, as well as the extent of the possible negative carbon footprint by adding CCS to the process leading to HyBECCS approaches, are to be considered in this assessment step. It should be mentioned that HyBECCS projects can have multiple impacts on the environment, such as acidification and eutrophication or the depletion of the ozone layer and abiotic resources [53]. Even though all environmental impacts are equally important, they are not included in the following estimation, as it is limited to considerations on climate mitigation.

First, the carbon-neutral energy output of the biohydrogen process can be expressed by an equivalent mass of other energy carriers, which could be substituted $\left(m_{s u b s, x}\right)$. This step can be realized by dividing the bioenergy potential $(B E P)$ by the $L H V$ of other energy carriers $\left(L H V_{x}\right)$, see Equation (4). At the same time, the saved amount of $\mathrm{CO}_{2}$ emissions $\left(m_{\mathrm{CO}_{2}, x}\right)$ can be calculated by dividing the energy output of the biohydrogen process by respective $\mathrm{CO}_{2}$ emission factors from other energy carriers $\left(e f_{x}\right)$, see Equation (5).

$$
\begin{gathered}
m_{\text {subs, } x}=\frac{B E P}{L H V_{x}} \\
m_{\mathrm{CO}_{2}, x}=\frac{B E P}{e f_{x}}
\end{gathered}
$$

The considered fossil energy carriers to be substituted are natural gas, coke, hard coal, and heavy fuel oil and hydrogen from natural gas steam reforming and water electrolysis powered by the German electricity mix. Further, green hydrogen from renewable electrical power can be considered. The fossil energy sources were chosen for comparison, as they are currently used in potential future application fields for hydrogen (e.g., steel industry, (heavy-duty) traffic, heat generation). The alternative hydrogen generation options highlight the direct benefits of biohydrogen (with and without CCS) as compared to other energy sources. Reference values for $L H V_{x}$ and $e f_{x}$ can be seen in Table 4 . 
Table 4. Reference values for various energy carriers.

\begin{tabular}{|c|c|c|c|}
\hline Energy Carrier & $L H V_{x}$ in $M J / k g$ & $e f_{x}$ in $t_{\mathrm{CO}_{2}} / \mathrm{TJ}$ & References \\
\hline Natural gas (NG) & $47.4^{3}$ & 56 & [54] (p. 138) \\
\hline Coke $(\mathrm{C})$ & 27.6 & 105 & [54] (p. 138) \\
\hline Hard coal (HC) & 28.3 & 93 & [54] (p. 138) \\
\hline Heavy fuel oil (HFO) & 39.5 & 81 & [54] (p. 138) \\
\hline $\mathrm{H}_{2}$ steam reforming $(\mathrm{SR})^{1}$ & 120 & 67 & \multirow{3}{*}{$\begin{array}{r}\text { [36] (p. 239) } \\
\text { [55] (Table 1) }\end{array}$} \\
\hline $\mathrm{H}_{2}$ electrolysis electricity mix $(\mathrm{EM})^{2}$ & 120 & 83 & \\
\hline $\mathrm{H}_{2}$ electrolysis renewables (REN) ${ }^{2}$ & 120 & 0 & \\
\hline
\end{tabular}

HyBECCS was introduced in Section 2.2. as an innovative way to produce carbonnegative hydrogen and is considered as an evaluation step in this work. The methodical conduct to obtain a theoretically storable amount of $\mathrm{CO}_{2}$ through HyBECCS is defined as follows: The mass of the product gas mixture $\left(m_{\text {gas }}\right)$ in the respective biohydrogen process and its $\mathrm{CO}_{2}$ content $\left(x_{\mathrm{CO}_{2}}\right)$ must be known or estimated. It should be noted that the real $\mathrm{CO}_{2}$ production rate often is a matter of uncertainty and depends largely on the composition of the input substrate. Real data are therefore to be preferred for the specific process. The resulting amount of $\mathrm{CO}_{2}$ produced during the biohydrogen process can be calculated according to Equation (6). This can be seen as the theoretical amount of storable biogenic carbon dioxide leading to the same value of theoretically achievable negative emission potential (NEP) in $\mathrm{CO}_{2, \text { eq }}$ through the specific HyBECCS approach.

$$
\mathrm{NEP}=x_{\mathrm{CO}_{2}} \cdot m_{g a s}
$$

\section{Discussion}

This section discusses the conducted work. First, the considered material flows are briefly touched upon. Next, limiting factors and assumptions are taken up and evaluated in light of associated uncertainties, restrictions, and alternative points of view.

Initially, a range of biomasses applicable to the process can be determined using the methodological approach presented. The decision to exclude by-products and biomass, which can be used as material resources, is a very important first restriction. Utilizing industrial residues, for instance, which are commonly used as animal feed, could create shortages in the supply for animal feed production. Consequently, this shortage would have to be filled by other resources. In terms of sustainable impact, those resources could possibly be of higher value, such as maize or soy, resulting in a shortage for human consumption so that in the further course these resources would have to be imported from other countries. This is just one example of emerging competition for usage, especially of relevance with industrial residues. In fact, the efficient use of by-products saves a lot of resources and energy as they fulfill demand, which otherwise would have to be satisfied elsewhere, potentially in a more energy-intensive manner. For those reasons, the material considered in this work is chosen to not present competition in material usage. Theoretically, industrial residues, animal-processing wastes, or oils and fats, amongst others, could still be used in biohydrogen production processes. However, the consideration of such material would have to be conducted in greater detail for specific regions or industries, as several sources indicate that nationwide data for industry by-products and other smaller biomass fractions are not available or based on vague assumptions. Hence, the respective data embody broad spreads and limited reliability [20] (p. 17), [22] (p. 103), [42] (p. 108).

An initial and expected finding based on the methodological approach shown in this paper is that pretreatment-especially hygienization-has an extensive impact on the bioenergy potential. The additional step of including other means of treatment, though not being necessary in the same sense as hygienization, can be reasoned by the expected increased degree of mobilization and the resulting enhanced process outputs. Altogether, 
the reliability of the obtained energy values and substrate properties can be considered as high, as they are taken from scientific papers. Associated risk factors are, on the one hand, the requirement of pressure sterilization in case of insufficient sterilization performance of pasteurization. On the other hand, the necessity to extract utilizable substances from the substrate could be required. Both of these factors could significantly increase pretreatment energy demand. Next, the process energy demand is an essential factor as well. The uncertainties concerning the process energy demand are associated with inaccuracies. Additional energy demand might result from further heat demand for process operation, for instance. Overall, a conservative approach has to be chosen to evaluate the processes.

The derivation of environmental impacts can provide an initial basis for decisions on the sustainability of the processes. Other relevant aspects, however, are substrate logistics and storage, as well as the handling of process residues, which have not been considered in the methodological approach presented. These topics were beyond the scope of this work but might pose certain risks or chances. For example, lengthy substrate transportation or improper storage could decrease the overall net potential of the biohydrogen processes, depending on the hauling distance or the loss of utilizable substances during storage. On the contrary, process residues might contain substances to be metabolized in further energetic treatment or biomass with high-value components. As a result, extraction of such high-value components, further energy generation from the substrate, or just compost producible from it could improve the economic and ecological value of the process.

The methodological approach shows weaknesses regarding process-specific developments. Some of those factors affecting the amount of available waste materials could be increased awareness of food waste, changing consumption habits, and the population trend. Regulatory measures, policy goals, and environmental concerns have been considered to some extent, but not in greater detail. It is considered acceptable to assume a status quo situation for these factors in the short term but has to be adjusted for the evaluation of long-term potentials. This work provides a starting point for evaluating bioenergy and climate mitigation potentials by providing a quickly implementable guide for estimating the bioenergy potential for hydrogen production from biomass and its potential greenhouse gas savings in Germany. However, many technology-specific factors that influence these potentials remain unconsidered. In addition to substrate suitability and conditions like wetness and hydrogen yield, these include, for example, technology maturity, energy efficiency, conversion rates, and plant complexity, in order to obtain a conclusive picture for the assessment. In addition, other environmental impact categories according to DIN EN ISO 14040/44, besides global warming potential, such as acidification and eutrophication potential or photochemical oxidant formation, as well as ozone layer and abiotic depletion, should be considered within holistic assessments.

\section{Summary and Prospect}

It is common ground that the future energy market requires efficient carbon-neutral or negative solutions in green energy production. Biohydrogen production technologies are expected to be capable of producing large amounts of hydrogen from organic biomass in the near future. Further, co-produced biogenic carbon dioxide can be stored or put to longterm use by applying hydrogen bioenergy with carbon capture and storage (HyBECCS) approaches to generate greenhouse gas sinks. This work aims to provide a guideline for deriving the bioenergy potential of organic waste material and the connected ecological impacts of biohydrogen and HyBECCS processes in Germany.

A four-step methodical conduct, including material selection, assumptions, calculation of energy potential, and environmental impact evaluation, is elaborated to achieve the desired outcome. First, biomass categories are evaluated regarding their applicability to an exemplary biohydrogen process. Therefore, a six-step selection process to exclude material is conducted, resulting in specific biomass categories found to be utilizable and fulfilling the criteria of waste material. Second, a number of assumptions regarding the pretreatment of the substrate and the required process energy demand are made 
to include the energy input required by the process. Third, the derivation of energy potentials is conducted following common practice and adhering to certain criteria for comparability and transparency. Lastly, the substitutable amount of (fossil) energy carriers and related emission savings, on the one hand, and the negative emissions by applying HyBECCS approaches, on the other hand, are evaluated to obtain a statement about the environmental benefits. The scientific contribution of this article was to develop a methodological approach for a bioenergy potential and a negative emission potential analysis illustrated using a fictitious fermentative hydrogen production process, rather than research based on experimental studies.

In conclusion, rising demand and a functioning hydrogen market are not only expected in Germany, but throughout Europe, which is key to triggering scaling effects and research progress for biohydrogen processes and HyBECCS approaches [2] (p. 5). Therefore, the use of hydrogen as an energy source in the transport sector and decisive industries (steel, cement, and chemical) is desired. These industries play a key role in the development of a German hydrogen market. In addition, the often decentralized produced hydrogen needs to be distributed all over the continent, demanding a modern network of storage and pipelines, suitable for safe $\mathrm{H}_{2}$ transport. Safety concerns and the applicability of existing infrastructure are to be evaluated and resolved on the part of the German government. Lastly, research on and development of hydrogen production, storage, distribution, and utilization are still in their early stages. This means that technologies are often not advanced enough for market rollout. More applied research and development are needed on biohydrogen processes and HyBECCS approaches as they can contribute to climate mitigation targets to a large extent [5]. Additionally, the new technologies need to be fully analyzable and evaluable during the innovation and upscaling processes in order to be successful on the market and prove their ecological potential. Therefore, the ecological and economic potential including all life cycle costs and emissions should be further investigated and a common framework be created, since the competitive performance is the main short-term indicator of success for biohydrogen processes in Germany. Additionally, the processes need to be compared to the competitive utilization technologies for various biomass flows in order to see whether biohydrogen production can be a better option in terms of energy output, carbon emissions, and life cycle impact. In addition, other impact categories besides global warming potential, such as acidification and eutrophication potential or photochemical oxidant formation, as well as ozone layer and abiotic depletion, should be considered using the LCA method according to DIN EN ISO 14040/44. This work, however, provides a starting point for investigating bioenergy and climate mitigation potentials.

Author Contributions: Writing, J.F. and M.T.; supervision, R.M. and A.S. All authors have read and agreed to the published version of the manuscript.

Funding: This research was funded by the German Federal Ministry for Economic Affairs and Energy.

Institutional Review Board Statement: Not applicable.

Informed Consent Statement: Not applicable.

Data Availability Statement: Not applicable.

Acknowledgments: The research shown in this paper was conducted within the project "RhoTech" (FKZ 03EI5407C). The authors gratefully acknowledge the financial support of the German Federal Ministry for Economic Affairs and Energy.

Conflicts of Interest: The authors declare no conflict of interest.

\section{References}

1. IPCC. Climate Change 2021: The Physical Science Basis. Contribution of Working Group I to the Sixth Assessment Report of the Intergovernmental Panel on Climate Change; Masson-Delmotte, V., Zhai, P., Pirani, A., Connors, S.L., Péan, C., Berger, S., Caud, N., Chen, Y., Goldfarb, L., Gomis, M.I., et al., Eds.; Cambridge University Press: Cambridge, UK, 2021; In Press.

2. BMWi. The National Hydrogen Strategy, Federal Ministry for Economic Affairs and Energy, Berlin. 2020. Available online: https: //www.bmwi.de/Redaktion/DE/Publikationen/Energie/die-nationale-wasserstoffstrategie.html (accessed on 4 March 2021). 
3. Juhrich, K. $\mathrm{CO}_{2}$ Emission Factors for Fossil Fuels. 2016. Available online: https://www.umweltbundesamt.de/sites/default/fil es/medien/1968/publikationen/co2_emission_factors_for_fossil_fuels_correction.pdf (accessed on 26 March 2021).

4. Full, J.; Merseburg, S.; Miehe, R.; Sauer, A. A new perspective for climate change mitigation-introducing carbon-negative hydrogen production from biomass with carbon capture and storage (HyBECCS). Sustainability 2021, 13, 4026. [CrossRef]

5. Agentur für Erneuerbare Energien. Bundesländer-Übersicht zu Erneuerbaren Energien (Overview Renewable Energies). Renewable Energies Agency (AEE). 2019. Available online: https:/ / bit.ly/3s3ws6s (accessed on 4 March 2021).

6. Schmid, C.; Horschig, T.; Pfeiffer, A.; Szarka, N.; Thrän, D. Biogas upgrading: A review of national biomethane strategies and support policies in selected countries. Energies 2019, 12, 3803. [CrossRef]

7. Weide, T.; Feil, F.; Kamphus, S.; Peitzmeier, J.; Brügging, E. Bio- $\mathrm{H}_{2}$ aus Organischen Reststoffen Mittels Dunkler Fermentation in Deutschland und den Niederlanden. 2020. Available online: http://www.biohydrogen.eu/wp-content/uploads/2020/09/2020 -09-18-Wasserstoff-Potential-DE-NL_final.pdf (accessed on 4 March 2021).

8. Thomassen, G.; van Dael, M.; van Passel, S.; You, F. How to assess the potential of emerging green technologies? Towards a prospective environmental and techno-economic assessment framework. Green Chem. 2019, 21, 4868-4886. [CrossRef]

9. Naqvi, S.; Ali, I.; Nasir, S.; Taqvi, S.A.A.; Atabani, A.E.; Chen, W. Assessment of agro-industrial residues for bioenergy potential by investigating thermo-kinetic behavior in a slow pyrolysis process. Fuel 2020, 278. [CrossRef]

10. Thrän, D.; Bauschmann, M.; Dahmen, N.; Erlach, B.; Heinbach, K.; Hirschl, B.; Hildebrand, J.; Rau, I.; Majer, S.; Oehmichen, K.; et al. Bioenergy beyond the German "Energiewende"-Assessment framework for integrated bioenergy strategies. Biomass Bioenergy 2020, 142, 105769. [CrossRef]

11. Long, H.; Li, X.; Wang, H.; Jia, J. Biomass resources and their bioenergy potential estimation: A review. Renew. Sustain. Energy Rev. 2013, 26, 344-352. [CrossRef]

12. Fu, T.; Ke, J.H.; Zhou, S.; Xie, G.H. Estimation of the quantity and availability of forestry residue for bioenergy production in China. Resour. Conserv. Recycl. 2020, 162, 104993. [CrossRef]

13. Batidzirai, B.; Smeets, E.M.W.; Faaij, A.P.C. Harmonising bioenergy resource potentials-Methodological lessons from review of state of the art bioenergy potential assessments. Renew. Sustain. Energy Rev. 2012, 16, 6598-6630. [CrossRef]

14. Bharti, A.; Paritosh, K.; Mandla, V.R.; Chawade, A.; Vivekanand, V. GIS Application for the Estimation of Bioenergy Potential from Agriculture Residues: An Overview. Energies 2021, 14, 898. [CrossRef]

15. European Environment Agency (EEA). EU Bioenergy Potential from a Resource-Efficiency Perspective; EEA: Brussels, Belgium, 2013; Volume 6, ISBN 9789-2921-3397-9.

16. Winkler, B.; Lemke, S.; Lewandowski, I. IREPA-Biomass for Bioenergy Potential Assessment by a Holistic and Participatory Approach. In Proceedings of the European Biomass Conference and Exhibition Proceedings, Vienna, Austria, 4 June 2015; pp. 273-281. Available online: https:/ / doi.org/10.5071/23rdEUBCE2015-1CV.3.21 (accessed on 17 November 2021).

17. BMWi. Gesetz zur Änderung des Erneuerbare-Energien-Gesetzes und Weiterer Energierechtlicher Vorschriften. 2021. Available online: https://www.bmwi.de/Redaktion/DE/Artikel/Service/gesetz-zur-aenderung-des-eeg-und-weiterer-energierechtlic her-vorschriften.html (accessed on 1 April 2021).

18. Umweltbundesamt. Waste Statistics. 2016. Available online: https://www.umweltbundesamt.de/en/topics/waste-resources/w aste-management/waste-statistics (accessed on 1 April 2021).

19. Thrän, D.; Adler, P.; Brosowski, A.; Fischer, E.; Herrmann, A.; Majer, S.; Oehmichen, K.; Pfeiffer, D.; Schmersahl, R.; Schröder, T.; et al. Method Handbook-Material Flow-Oriented Assessment of Greenhouse Gas Effects. 2015. Available online: https://www.energetische-biomassenutzung.de/fileadmin/media/6_Publikationen/04_MHB_en_web.pdf (accessed on 25 March 2021).

20. Köppel, W.; Erler, R.; Senner, J.; Kiefer, J. Einsatz Von Industriellen Und Kommunalen Abfallstoffen für die Biogaseinspeisung 2014. Available online: https://www.dvgw.de/medien/dvgw/forschung/berichte/g1_08_10.pdf (accessed on 9 March 2021).

21. Brosowski, P.; Adler, G.; Erdmann, W.; Stinner, D.; Thrän, U.; Mantau, C.; Blanke, B.; Mahro, T.; Hering, G. Reinholdt, Biomassepotenziale von Rest- und Abfallstoffen- Status quo in Deutschland. 2015. Available online: https://mediathek.fnr.de/b and-36-biomassepotenziale-von-rest-und-abfallstoffen.html (accessed on 9 March 2021).

22. Fehrenbach, H.; Giegrich, J.; Köppen, S.; Wern, B.; Pertagnol, J.; Baur, F.; Hünecke, K.; Dehoust, G.; Bulach, W.; Wiegmann, K. BioRest: Verfügbarkeit und Nutzungsoptionen biogener Abfall- und Reststoffe im Energiesystem (Strom-, Wärme- und Verkehrssektor). 2019. Available online: https://www.umweltbundesamt.de/sites/default/files/medien/1410/publikationen/2019-09-24_te xte_115-2019_biorest.pdf (accessed on 9 March 2021).

23. Knappe, F.; Vogt, R.; Turk, T.; Hüttner, A.; Dehoust, G.; Schneider, T. Hochwertige Verwertung von Bioabfällen-Ein Leitfaden. 2015. Available online: https://pudi.lubw.de/detailseite/-/publication/94776 (accessed on 2 April 2021).

24. Scholwin, F.; Grope, J.; Clinkscales, A.; Daniel-Gromke, J.; Rensberg, N.; Denysenko, V.; Stinner, W.; Richter, F.; Raussen, T.; Kern, M.; et al. Thomas and Reinhold, Aktuelle Entwicklung und Perspektiven der Biogasproduktion aus Bioabfall und Gülle. 2019. Available online: https://www.umweltbundesamt.de/sites/default/files/medien/1410/publikationen/2019-04-15_te xte_41-2019_biogasproduktion.pdf (accessed on 11 March 2021).

25. Mühlenhoff, J.; Dannemann, B. Biogene Rest- und Abfallstoffe-Flexibler Baustein der Energiewende. Renews Spez. 2017, 81, 18.

26. Knappe, F.; Vogt, R.; Lazar, S.; Höke, S. Optimierung der Verwertung Organischer Abfälle. 2012. Available online: https: //www.umweltbundesamt.de/sites/default/files/medien/461/publikationen/4310.pdf (accessed on 12 March 2021). 
27. Zeller, V.; Gröngröft, A.; Kirsten, C.; Weller, N.; Schenker, M.; Wedwitschka, H.; Wagner, B.; Deumelandt, P.; Reinicke, F.; Vetter, A.; et al. Basisinformationen Für Eine Nachhaltige NUTZUNG von Landwirtschaftlichen Reststoffen zur Bioenergiebereitstellung. 2012. Available online: https://www.energetische-biomassenutzung.de/fileadmin/user_upload/Downloads/Ver \%C3\%B6ffentlichungen/02_Basisinformationen_Reststoffe_web.pdf (accessed on 12 March 2021).

28. BMU. Abfallwirtschaft in Deutschland 2020-Fakten, Daten, Grafiken. 2020. Available online: https://www.bmu.de/fileadmin/D aten_BMU/Pools / Broschueren/abfallwirtschaft_2020_bf.pdf (accessed on 18 March 2021).

29. Destatis. Waste Balance 2018. 2020. Available online: https://www.destatis.de/EN/Themes/Society-Environment/Environmen t/Waste-Management/Tables/liste-brief-overview-waste-balance.html (accessed on 10 March 2021).

30. BMBF. Eine Kleine Wasserstoff-Farbenlehre. 2020. Available online: https:/ / bit.ly/3mJz07R (accessed on 12 April 2021).

31. Pandey, A.; Chang, J.-S.; Hallenbeck, P.C.; Larroche, C. (Eds.) Biohydrogen-Biomass, Biofuels, Biochemicals, 2nd ed.; Elsevier: Amsterdam, The Netherlands, 2013; ISBN 9780-4446-4203-5.

32. Poullikkas, A.; Al-Assaf, Y.; Kalamaras, C.M.; Efstathiou, A.M. Hydrogen production technologies: Current state and future developments. Conf. Pap. Energy 2013, 690627, 1-9. [CrossRef]

33. Wang, J.; Yin, Y. Biohydrogen Production from Organic Wastes; Springer: Berlin/Heidelberg, Germany, 2017; ISBN 9789-8110-4675-9.

34. Dincer, I.; Acar, C. Review and evaluation of hydrogen production methods for better sustainability. Int. J. Hydrog. Energy 2015, 40,11094-11111. [CrossRef]

35. Kapdan, I.K.; Kargi, F. Bio-hydrogen production from waste materials. Enzym. Microb. Technol. 2006, 38, 569-582. [CrossRef]

36. Singh, A.; Rathore, D. (Eds.) Biohydrogen Production: Sustainability of Current Technology and Future Perspective, 1st ed.; Springer: Berlin/Heidelberg, Germany, 2017; ISBN 9788-1322-3577-4.

37. Ghosh, R.; Grammel, H.; Sauer, A. Neue Strategie zur Wasserstoff-Produktion aus Frucht- und Molkereiabfällen mit Hilfe von Purpurbakterien. Available online: https://www.energetische-biomassenutzung.de/projekte-partner/details/project/show/ Project/rhotech-637/ (accessed on 3 April 2021).

38. Zeiger, L.; Grammel, H. Model-based high cell density cultivation of Rhodospirillum rubrum under respiratory dark conditions. Biotechnol. Bioeng. 2010, 105, 729-739. [CrossRef]

39. Bui, M.; Adjiman, C.S.; Bardow, A.; Anthony, E.J.; Boston, A.; Brown, S.; Fennell, P.S.; Fuss, S.; Galindo, A.; Hackett, L.A.; et al. Carbon capture and storage (CCS): The way forward. Energy Environ. Sci. 2018, 11, 1062-1176. [CrossRef]

40. Full, J.; Miehe, R.; Kiemel, S.; Bauernhansl, T.; Sauer, A. The Biological Transformation of Energy Supply and Storage-Technologies and Scenarios for Biointelligent Value Creation. Procedia Manuf. 2019, 39, 1204-1214. [CrossRef]

41. Miehe, R.; Bauernhansl, T.; Beckett, M.; Brecher, C.; Demmer, A.; Drossel, W.-G.; Elfert, P.; Full, J.; Hellmich, A.; Hinxlage, J.; et al The biological transformation of industrial manufacturing-Technologies, status and scenarios for a sustainable future of the German manufacturing industry. J. Manuf. Syst. 2020, 54, 50-61. [CrossRef]

42. Gaida, B.; Schüttmann, I.; Zorn, H.; Mahro, B. Bestandsaufnahme zum biogenen Reststoffpotential der deutschen Lebensmittel und Biotechnik-Industrie. 2013. Available online: https://www.fnr-server.de/ftp/pdf/berichte/22001910.pdf (accessed on 9 March 2021).

43. Kopf, K.A.; Bisig, W.; Jungbluth, N.; Denkel, C. Quantitatives Potenzial zur Verwertung von Molke in Lebensmitteln in der Schweiz. Agrar. Schweiz 2015, 6, 270-277. [CrossRef]

44. Aschmann, V.; Effenberger, M.; Gronauer, A.; Kaiser, F.; Kissel, R.; Mitterleitner, H.; Neser, S.; Schlattmann, M.; Speckmaier, M.; Ziehfreund, G. Biogashandbuch Bayern-Grundlagen und Technik. 2007. Available online: https://www.lfu.bayern.de/energie/ biogashandbuch/index.htm (accessed on 15 March 2021).

45. Pospiech, J.; Ullrich, M.; Göttling, S.; Truyen, U.; Speck, S. Hygienisierung von Wirtschaftsdünger und Gärresten. 2014. Available online: https:/ / nbn-resolving.org/urn:nbn:de:bsz:14-qucosa-161847 (accessed on 17 November 2021).

46. Vavouraki, A.I.; Angelis, E.M.; Kornaros, M. Optimization of thermo-chemical hydrolysis of kitchen wastes. Waste Manag. 2013, 33, 740-745. [CrossRef]

47. Patni, N.; Jui, P.Y. Volatile fatty acids in stored dairy-cattle slurry. Agric. Wastes 1985, 13, 159-178. [CrossRef]

48. Panesar, P.S.; Kennedy, J.F.; Gandhi, D.N.; Bunko, K. Bioutilisation of whey for lactic acid production. Food Chem. 2007, 105, 1-14. [CrossRef]

49. Fachagentur Nachwachsende Rohstoffe e. V. (n.d.). Faustzahlen. Available online: https://biogas.fnr.de/daten-und-fakten/fau stzahlen (accessed on 18 March 2021).

50. Bakonyi, P.; Nemestóthy, N.; Bélafi-Bakó, K. Biohydrogen purification by membranes: An overview on the operational conditions affecting the performance of non-porous, polymeric and ionic liquid based gas separation membranes. Int. J. Hydrog. Energy 2013, 68, 9673-9687. [CrossRef]

51. Ramírez-Morales, J.E.; Tapia-Venegas, E.; Toledo-Alarcón, J.; Ruiz-Filippi, G. Simultaneous production and separation of biohydrogen in mixed culture systems by continuous dark fermentation. Water Sci. Technol. 2015, 71, 1271-1285. [CrossRef]

52. Staffell, I. Zero carbon infinite COP heat from fuel cell CHP. Appl. Energy 2015, 147, 373-385. [CrossRef]

53. Fajardy, M.; Koeberle, A.; MacDowell, N.; Fantuzzi, A. BECCS deployment: A reality check. Grantham Inst. Brief. Pap. 2019, 28, 1-13.

54. DEHSt. Leitfaden zur Erstellung von Überwachungsplänen für Stationäre Anlagen-4. Handelsperiode (2021-2030). 2020. Available online: https:/ / bit.ly/31nG9Rz (accessed on 26 March 2021). 
55. Otto, A.; Robinius, M.; Grube, T.; Schiebahn, S.; Praktiknjo, A.; Stolten, D. Power-to-steel: Reducing $\mathrm{CO}_{2}$ through the integration of renewable energy and hydrogen into the German steel industry. Energies 2017, 10, 451. [CrossRef]

56. Umweltbundesamt. $\mathrm{CO}_{2}$ Emissions Per Kilowatt Hour of Electricity in Further Decline in 2019. 2020. Available online: https: //www.umweltbundesamt.de/presse/pressemitteilungen/bilanz-2019-co2-emissionen-pro-kilowattstunde-strom (accessed on 25 April 2021).

57. Pehnt, M. Energieeffizienz; Springer: Berlin/Heidelberg, Germany, 2010; ISBN 9783-6421-4250-5. 